\title{
Factors That Influence Farmer Adaptation to Climate Change (Case of Dry Land Farmers in Cemoro Watershed in Central Java)
}

\author{
Sugihardjo ${ }^{1}$,Eny Lestari ${ }^{1}$, Retno Setyowati ${ }^{1}$, Widiyanto $^{I}$, and Eksa Rusdiyana $^{1}$ \\ ${ }^{1}$ Department of Agriculture Extension and Communication, Faculty of Agriculture, Universitas Sebelas \\ Maret, Surakarta, Indonesia
}

\begin{abstract}
This study aims to determine the adaptation strategy of dry land farmers to climate change. The study was conducted in the Cemoro watershed area, Central Java, Indonesia with 120 respondents as dry land rice farmers. Sampling was done by proportional random sampling. Data were collected from March to November 2016. Data analysis was performed using the two-stage Heckman model approach. The results showed that farmers 'perceptions of climate change were significantly influenced by the area of farmland managed and farmers' income. The farmers' adaptation strategy to climate change is significantly affected by the level of education, the participation of farmers in social organizations, and the level of income.
\end{abstract}

\section{Introduction}

Climate change affects all human life sectors [1]. Asian Development Bank mentions that broadly, the sectors affected much by climate change are farming, water resource, forestry, ecosystem, and health [2]. As known, climate change can result in both flood and drought that can harm the sustainability of farming production process [3]. The farming sustainability process needs the optimum water supply to make the plant growing well. Water supply not available optimally will harm the farming output. Farmers as the manager of agribusiness, of course, expect to get good harvest output, and thereby their income can be used to suffice their life. However, the fact shows that climate change impacts the decreased farming productivity and production [4].

Some previous studies showed that climate change can harm the farmers' harvest output [5]. The drought occurring in dry land in Dharmaputri region, India, has decreased the farmers' harvest output [6]. The effect of climate change occurring in Indonesia will rice plant in 2050 will decrease the production by 20.3 percents compared with production in 2006. The result of study represents that the effect of climate change should be anticipated to reduce the higher risk [7].

The farmers as the manager of agribusiness should take some attempts to reduce the effect of climate change. One of them is to adapt to climate change. Adaptation is an action that can be taken to reduce a negative effect on climate change. Adaptation to climate change can be defined as an attempt taken to adapt to natural system or human to deal with the effect of climate change occurring or predicted to occur in order to mitigate hazard or to utilize the 
opportunity of benefiting from the effect of climate change [2]. Adaptation can be performed by the farmers to reduce the effect of climate change. Conducting adaptation takes money, but the expense of money can be compensated with the reduction of risk occurring otherwise.

The experience in some regions shows that adaptation conducted by farmers can reduce the risk of decreased production due to climate change. Farmers in Nepal adapting to climate change are capable of increasing the rice production [8]. This study suggested that government should improve farmers' knowledge and skill to adapt to climate change. Farmers adapting to climate change affect their production and income positively. Considering the results of previous studies, it can be summarized that adaptation to climate change should be implemented, aiming to mitigate the risk of lowered production and income [9].

Adaptation can be conducted either structurally or non-structurally. Structural adaptation is usually initiated by government. Structural adaptation is accomplished through improving physical facilities and farming production system resilience against the climate change threat [7]. Meanwhile, non-structural adaptation can be accomplished through developing cultural technology tolerant to climate grip, institutional reinforcement, legal drafting, and etc. the policy is intended to facilitate the farmers to adapt to climate change. Although government has provided the farmers with many policies and facilities in order to adapt to climate change, the farmers do not implement them automatically. It is because internal and external factors to be taken into account in adapting to the climate change. In addition, local adaptation should be taken into account by the farmers in implementing them. This research will study the adaptation strategy taken by rice farmers in dry land. In addition, it aims to find out the factors influencing the farmers in adapting to climate change in farmland.

\section{Method}

This research took place in Cemoro watershed (DAS) constituting Bengawan Solo Hulu Sub-Watershed. Administratively Cemoro Watershed is located in Central Java, Indonesia (See Attachment). Cemoro Watershed area includes some areas of Semarang Regency, Boyolali Regency, Karanganyar Regency and Sragen Regency. Cemoro Watershed upstream is in the west administratively belonging to Semarang Regency and Boyolali Regency and its downstream is in the east administratively belonging to Sragen and Karanganyar Regencies. The commodity cultivated in the research location is rice when the water is available and corn or peanuts after planting rice

This study was designed as descriptive quantitative research. The population of research was all dry-land rice farmers existing in Cemoro Watershed area. Sampling was conducted purposively considering the region's agroecological aspect; the sample consisted of 120 farmers. Data were collected from March to November 2016.

Data analysis was conducted using Heckman's two-stage model. In the first stage, the analysis was conducted on the factors influencing farmers' perception on climate change, consisting of external and internal factors. Probit model was used to find out the factors affecting the farmers' perception on climate change. This model was used because perception as dependent variable was divided into two: perceiving and not perceiving the climate change occurrence. The regression model is written as equation 1.

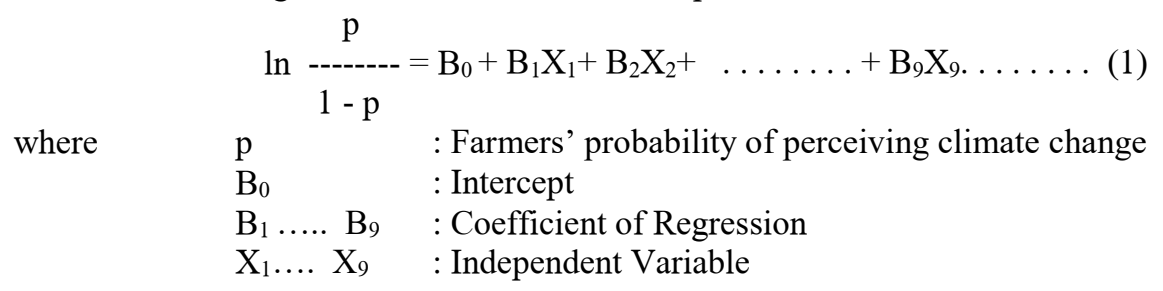


The second stage is to analyze the factors influencing farmer's adaptation to climate change. Analysis was conducted only on the farmers perceiving that climate change actually occurs. The adaptation to climate change variable was divided into two: adapting and not adapting. Thus, the regression model is shown in equation 2 .

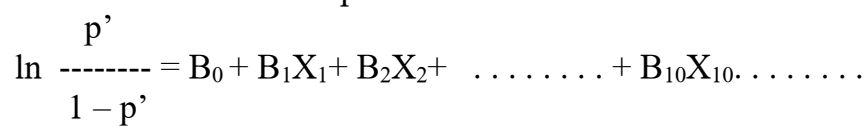

Where

$$
\begin{aligned}
& \text { p' : farmers' probability of taking adaptation strategy } \\
& \text { B0 : Intercept } \\
& \text { B1....B10 : Coefficient of Regression } \\
& \mathrm{X} 1 \ldots \mathrm{X} 10 \text { : Independent Variable }
\end{aligned}
$$

\section{Result and Discussion}

Adaptation to climate change is one of farmers' responses in dealing with climate that can be conducted either reactively or anticipatively. The word reactively means to plan the adjustment of activities before climate change. The current condition is the one when climate change has occurred; thus, farmers perform adaptation in the attempt of mitigating the loss due to climate change.

The farmers in the research location generally have adapted to the climate change. The adaptation attempts taken can be seen in Table 1. There are six forms of adaptation performed by the farmers. Each of farmers can usually take more than one adaptation attempt. Using new drought-resistant variety is the farmers' option in dealing with a long dry season. Meanwhile, for the flood-vulnerable region, farmers use the submersion-resistant variety. About 92.5 percents of farmers use new variety. This data indicates that the use of new variety has been a habit. This is in line with the rivew conducted by Akinnagbe and Irohibe that the use of new varieties is one way of adapting in the face of climate change [10]. Using pump is another attempt taken by farmers to deal with climate change. About 76.7 percents of farmers said using water pump to satisfy their plants' need for water. The water is usually taken from river or groundwater. Still another attempt taken by the farmers is to adjust planting time, meaning that the farmers start to plant only when the rainy season begins. It is done considering that the plants' need for much water for its growth can be sufficed by the existing rainwater. About 46.7 percents of farmers adapt the planting time. The farmers not adapting the planting time usually still apply "pranotomongso", the assignment of planting time believed in since ancestor time. The farmers also use organic fertilizer ( 41.7 percents), use natural pesticide ( 33.3 percent), and change planting pattern $(5,0$ percents) as other adaption attempts. Only a few farmers made changes to planting time. This is different from the results of research conducted in Ghana, where the number reached 22 percent [11]

Table1. Adaptation Attempts Taken by Farmers in Cemoro Watershed Area of Central Java to Deal with Climate Change

\begin{tabular}{|l|l|l|l|}
\hline \multirow{2}{*}{ No } & \multirow{2}{*}{ Adaptation Attempt } & \multicolumn{2}{|c|}{ Proportion (\%) } \\
\cline { 3 - 4 } & & Doing & Not Doing \\
\hline 1 & Adjusting planting time & 46.7 & 53.3 \\
\hline 2 & Planting new variety & 92.5 & 7.5 \\
\hline 3 & Changing planting pattern & 5.0 & 95.0 \\
\hline 4 & Using organic fertilizer & 41.7 & 58.3 \\
\hline 5 & Using natural pesticide & 33.3 & 66.7 \\
\hline 6 & Using water pump & 76.7 & 23.3 \\
\hline
\end{tabular}


These adaptation attempts are related indirectly to climate change but intended more to dealing with the probability of plant disturbance due to weeds pest, disease, or new generated by climate change.

From Table 1, it can be seen that nearly all farmers adapt to the change by means of using new variety. The reality indicates that farmers take more than one adaptation attempt to deal with climate change. It is intended to bring out optimum result.

For analysis purpose in this research, the farmers are said to adapt to the climate problems when they take at least two adaptation attempts to climate change, and one of which is to use new variety tolerant to climate change. If the farmers use new variety only but do not take other adaptation attempt, the farmers are considered as not adapting to climate change. Broadly, farmers adapting to the climate change can be classified into two groups: the one adapting to climate change and another using technology, despite simplicity. The first one consists of farmers taking adaptation attempt by means of adjusting planting time and changing planting pattern, in addition to using new variety. Meanwhile, the second group consists of farmers adapting through using pump to suck water, using natural pesticide and organic fertilizer. The result of analysis on the factors influencing farmers' perception on and adaptation to climate change using Heckman's model can be seen in Table 2.

Table 2. Factors Influencing Farmers' Perception and Adaptation to Climate Change

\begin{tabular}{|c|c|c|c|}
\hline No & Variable & Coefficient & Prop \\
\hline & Response-Perception Equation & & \\
\hline 1 & Constant & 3.3431 & 0.0595 \\
\hline 2 & Education Level & -0.0255 & 0.2028 \\
\hline 3 & Number of household members & 0.0401 & 0.4243 \\
\hline 4 & Farmland width & $0.5870 * * *$ & 0.0045 \\
\hline 5 & Number of Cattle & -0.0344 & 0.2711 \\
\hline 6 & Farming experience & 0.0044 & 0.4109 \\
\hline 7 & Income & $-0.1805 * *$ & 0.0751 \\
\hline 8 & Agricultural Extension & -0.0252 & 0.5397 \\
\hline 9 & Information on Climate & 0.1299 & 0.4097 \\
\hline \multirow[t]{2}{*}{10} & Organizational Participation & 0.0582 & 0.6870 \\
\hline & $\begin{array}{l}\text { Selection-ADAPTATION } \\
\text { Equation }\end{array}$ & & \\
\hline 1 & Constant & -9.6870 & 0.0068 \\
\hline 2 & Education Level & $-0.1156^{*}$ & 0.0244 \\
\hline 3 & Number of Household members & 0.1960 & 0.1439 \\
\hline 4 & Farmland Width & 0.1236 & 0.8671 \\
\hline 5 & Number of Cattle & -0.0321 & 0.7103 \\
\hline 6 & Farming Experience & 0.0100 & 0.5112 \\
\hline 5 & Agricultural Extension & 0.2362 & 0.6429 \\
\hline 8 & Information on Climate & 0.1303 & 0.8206 \\
\hline 9 & Organizational Participation & $-0.7785^{*}$ & 0.0853 \\
\hline 10 & Income & $0.6710^{* *}$ & 0.0038 \\
\hline 11 & Risk of Harvest failure & -0.0001 & 0.1420 \\
\hline
\end{tabular}

Generally, farmers will perform adaptation when they perceive that climate change will and has occurred indeed. Thus, in this first stage of study, an analysis was conducted on the factors influencing farmers' perception on climate change. The result of analysis indicated that farmland width and farmer income affect significantly their perception on climate change. Land width affects farmers' perception on climate change positively and 
significantly. The wider land cultivated affects positively the farmers' perception on climate change. It is likely because in cultivating the farmland the farmers pay more attention to their environmental condition.

Meanwhile, income affects the farmers' perception on climate change positively and significantly. Thus, the lower the income, the more positive is the farmers' perception on climate change. Through limited income, the farmers likely pay more attention to their environmental condition, particularly weather. Limited income the farmers have is very meaningful to their life sustainability. Thus, in running a farm, climate condition should be taken into account thoroughly to prevent the harvest failure from occurring.

Other variables such as education level, number of household members, number of cattle, farming experience, agricultural extension activity, information on climate, and participation in social organization do not affect farmers' perception on climate change significantly. This analysis shows that farmers' perception is not affected by those variables in the research location.

The next analysis was conducted on the farmers perceiving that climate change has occurred and will remain to occur. To the farmers perceiving that climate change will and has occurred, an analysis was conducted on the factors putatively affecting the farmers' adaptation to climate change. Out of ten variables putatively affecting the farmers' adaptation to climate change, only three variables have significant effect. They are education level, participation in social organization, and income level.

Education level has significant negative effect on farmers' adaptation to climate change at confidence level of $90 \%$. The result of research shows that the lower the education level, the higher is the probability of adapting to climate change. On the other hand, there is a positive correlation between education level and farmer's probability of adapting to climate change [9]. This difference is due to the different condition of farmers in the research site. The farmers in the research site are commonly old and have low education, so that they refer more to farming experience in running a farm. They run their farm by paying attention climate change for many years. Farmers consciously perform adaptation, because based on the experience they will have harvest failure if they do not do it. Meanwhile, farming is life support to suffice the family's needs.

Participation in social organization has negative significant effect at confidence level of 90. It means that the higher the farmers' activity of attending social organization activity, the lower is the probability of adapting to climate change. Considering the result of research, perhaps because the farmers' participation in non-agricultural activities has taken much time, they have no time to adapt to climate change in running their farm. Farmers' participation in organizational activity can actually increase insight. However, if the activity conducted takes much time, it will lead to the neglect of farming. Social institution contributes to the decision to adapt to climate change in Nigeria. This study found that social institution affects positively the farmers' adaptation to climate change [12].

Income level has positive significant effect at confidence level of 95 percents. The higher the farmers' income, the higher is the farmers' probability of adapting to climate change. Income is a capital to conduct adaptation to climate change. Adaptation must need cost (money); therefore it is reasonable that income level affects positively the probability of adapting to climate change. The farmers realize that the adaptation attempt must take money. However, considering the experience, if adaptation is not done to the climate change, the loss suffered from will be larger. Therefore, the higher the farmers' income, the larger is the capital to conduct adaptation to climate change [13][14].

Other variables have insignificant effect on farmers' adaptation to climate change. It indicates that farmland width, number of cattle owned, farming experience, agricultural extension activity, participation in social organization, information on climate, and harvest failure risk are not taken into account by the farmers in adapting to climate change. 


\section{Conclusion}

Basically, farmers have perceived the climate change. It can be seen from the farmers who have conducted adaptation. Some adaptation attempts have been taken to deal with climate change. The attempt taken most widely is to use variety resistant to climate change. Other attempts taken are to use water pump, to adjust planting time from the beginning of rainy season, and to use organic fertilizer and pesticide.

Farmers' adaptation to climate change is influenced by education level, participation in social organization, and income level. Education level and participation in social organization relate negatively and significantly to the adaptation to climate change. Meanwhile, income level affects farmers' adaptation to climate change positively and significantly.

\section{References}

1. E. Kevin Trenberth. . Climate change caused by human activities is happening and it already has major consequences. Journal of Energy \& Natural Resources Law. 36, 463$481(2018)$

2. ADB (Asian Development Bank). Ekonomi Perubahan Iklim di Asia Tenggara: TinjauanRegional-Intisari. Metro Manila, Philippina (2009)

3. C. Li , T, Zuo., and R, Rabina G., Farmer's Adaptation to Climate Risk in the Context of China, Agriculture and Agricultural Science Procedia 1:116-125 (2010)

4. I. Lipińska. J. Eur Count. Managing the Risk in Agriculture Production: The Role of Government. 8, 86-97 (2016)

5. R. Naylor,Battisti, D.S., Vimon D.J., Falcon W.P., and Burke, M.B. Proceeding of National Academy of Science of the United State of America PNAS 1004, Assessing Risks of Climate Variability and Climate Change fo Indonesia Rice Agriculture, 19 : $7752-7757$ (2007)

6. S. Angles. M, Chinnadurai, and Sundar. J. Agri Eco. Awareness on impact of climate change on dry land agriculture and coping mechanisms of dr yland farmers. 66, 365-372 (2011)

7. I. Handoko, Y. Sugiarto, Y. Syaukat. Keterkaitan Perubahan Iklim dan Produksi Pangan Strategis:Telaah Kebijakan Independen dalam Bidang Perdagangan dan Pembangunan (2008)

8. U. Khanal, W. Clevo, H. Viet-Ngu, L. Boon. 2018. J. Ecolog Eco. Farmers' Adaptation to Climate Change, Its Determinants and Impacts on Rice Yield in Nepal. 144, 139-147 (2018)

9. M. Abid, A. Uwe, Schneide, S. Jürgen. J. Rur Stud. Adaptation to climate change and its impacts on food productivity and cropincome: Perspectives of farmers in rural Pakistan. 47 (A) 254-266 (2016)

10. O. Akinnagbe M and Irohibe, I J. Bangladesh J. Agril. Res Agricultural Adaptation Strategies to Climate Change Impacts in Africa : a Reviev. 39(3): 407-418 (2014)

11. F. Ndamani, Tsunemi W. Sci. Agric. Determinants of farmers' adaptation to climate change: A micro level analysis in Ghana 79 (3): 201-208 (2016)

12. T. Ojol T and J. S. Baiyegunhi. J Land Use Pol. Determinants of Climate Change Adaptation Strategi and ItsImpact on Farm Income of Ric Farmers in South-West Nigeria. 95, 103946 (2019) 
13. T. Gutu, E. Bezabih and K. Mengistu. J. Agri Scie and Soil Scie. Econometric Analysis of Local Level Perception, Adaptation and Coping Strategi to Climate Change Induced Shocks in North Sewa, Ethiopia. 2, 347-363 (2012)

14. O. Obayelu, L. Abimbol O. A. Tolulope I. J. Agri and Env for Inter Dev. Factor Influencing Farmers' Choices of Adaptatition to Climate Change in Ekiti State, Nigeria. 108, 3 -16 (2014) 